Modern Trends in Endocrinology (2nd Series)

Edited by H. Gardiner-HiLl, M.B.E., M.D., F.R.C.P. Pp. $x+333+$ index, with 43 figures. London: Butterworth. 1961. $75 s$.

A further distinguished group of research workers and clinicians contribute to the second series of this book. The Editor points out in the preface that the volume is both complimentary and supplementary to the first series, published in 1958 , but in no way replaces it.

Although the thyroid and adrenal hormones were dealt with in the first series, there are welcome chapters in the new book on auto-immunity in thyroid disease and on primary and secondary aldosteronism. Certain chapters will be of especial interest to research workers, dealing with current theories and advances in subjects outside their direct field of activity. From the clinical point of view, there are excellent chapters on hypoglycæmia, therapeutic pituitary ablation, surgical treatment of Cushing's syndrome, oral hypoglycæmic agents, anabolic steroids, oral contraceptive agents and human sex anomalies.

Although the bibliographies are full, the titles of articles referred to in the text are included in those of certain chapters but not in those of others, an omission which could be rectified with advantage.

The book, which is excellently produced, is recommended to everyone, whether engaged in research or in clinical medicine; it will be of especial value to postgraduates who wish to find, within one cover, information on the rapid advances which are taking place in the endocrine field.

\section{Lymphocytes and Mast Cells}

Margaret A. Kelsall, B.A., M.A., PH.D., and EdWard D. Crabbe, B.A., M.A., PH.D. Pp. xvi + 399, with $3 \mathrm{I}$ illustrations. London: Bailliére, Tindall \& Cox. 1959. 64s.

Drs. Kelsall and Crabbe have attempted to review all contributions to the knowledge of the nature of lymphocytes, plasma cells or mast cells. They have, in effect, summarized an enormous amount of relevant literature, arranged it in appropriate sections, and added their own views and experience where applicable. Although well laid out, the inevitable result tends to be a series of rather loosely linked facts and theories which emphasize how much interest has been taken in these cells, and how little is really known about their function. Much of the content of this book will be new to pathologists, and many stimulating and fascinating fragments emerge from even a casual examination, but the amount of compression necessary in a work of this type, together with a rather ponderous literary style does not make for easy reading. However, it is presumably intended mainly as a work of reference, and as such, fulfils its purpose admirably. References in the text are clearly and unobtrusively numbered; the bibliography occupies about one-tenth of the book, and contains some 1,140 references. It is to be hoped that subsequent editions will appear, including more recent references, and maintaining the same encyclopædic standard.

\section{Preventive Medicine and Public Health}

An Introduction for Students and Practitioners.

FRED GRUNDY, M.D., M.R.C.P., D.P.H. Fourth edition. Pp. viii +316 , illustrated. London: H. K. Lewis. 1960. $27 s .6 d$.

The reader feels at once that he is on safe ground with Professor Grundy. He is told plainly what he can expect and what he can not expect. The book is a students' book first and foremost - and that means not that it is a 'textbook', but that it is a real help when you want to know anything. You can easily find the section required (only five of the 18 chapters have more than 20 pages and the largest chapter has 26 pages) and the information is probably there. By 'students' I mean the undergraduate- and also the enquiring general practitioner or hospital doctor.

The author is good at explaining things simply and shortly: not a common gift. Certain chapters are quite obviously for reference. No one in their senses would dream of reading them, but those which are for reading should be read closely without any skipping. The author has already done all the skipping that is justifiable.

This small volume (under 300 pages of moderate size) is well and clearly printed on good paper. I wish that the same compliment could be paid to the binding. No books are cheap today, but there are few other things a medical student or practitioner can get for $27 s$. $6 d$. which will be of greater use to him than this book.

\section{Coronary Vasodilators}

R. Charlier. Pp. $x i+208$, illustrated. Oxford, London, New York and Paris: Pergamon Press. 1961. 55 s.

This interesting textbook is written by the head of a pharmacology department in Brussels. It is presented in a readable and factual style. The physiology of coronary blood flow, the design of clinical trials of antianginal agents, and the pharmacology of the coronary vasodilators are discussed in detail. The space given to the conventional anticoagulants (only heparin and dicoumarol are included) is, however, rather scanty and no reference is given to the good results obtained in select groups of patients with angina pectoris in recent years.

The completeness of the bibliography may be ascertained from the 52 pages and 908 references in a book containing 150 pages of text. It seems a pity, however, that small, useful books of this type should be published at such a prohibitive price.

\section{A Short Textbook of Hæmatology}

R. B. Thompson, M.D., F.R.C.P. Pp. 306, illustrated. London: Pitman Medical Publishing Company. 1961. 30 .

This is an admirably short text of haematology. Such a comprehensive presentation of the subject, perforce at a general level, must ensure popularity. It is written in an enviably easy style, is factually correct and compares very favourably with sections on hæmatology in the standard text-books of general medicine produced in this country.

There is no section on laboratory techniques and the coloured illustrations, which are not of high quality, do not enhance the value of the book, though they must add to the cost.

These criticisms apart, the book must be warmly praised. Basic information about blood cells, about iron, vitamin $\mathrm{B}_{12}$ and folic metabolism, about hæmostasis and about the lymphomatous diseases is given with clarity and balance. Clinical descriptions are good. The short statements on the management of leukæmia and Hodgkin's disease deserve to be read by every physician handling such patients, for their humane commonsense.

As an introduction to hæmatology this book can be warmly recommended. 